\title{
NATURAL OCCURRENCE OF Pasteuria nishizawae IN SOYBEAN AREAS
}

\author{
OCORRÊNCIA NATURAL DE Pasteuria nishizawae EM ÁREAS DE SOJA
}

\author{
Camilla Buiatti VICENTE ${ }^{1}$; Maria Amelia dos SANTOS ${ }^{2}$ \\ 1. Engenheira Agrônoma, Mestre em Fitopatologia pela Universidade Federal de Uberlândia - UFU, Syngenta, Uberlândia, MG, Brasil; \\ 2. Professora, Doutora, Instituto de Ciências Agrárias - ICIAG - UFU, Uberlândia, MG, Brasil.
}

\begin{abstract}
Soybean (Glycine $\max$ (L.) Merrill) is a widely grown crop of economic prominence. Brazil is considered as the second largest worldwide producer and exporter. Soybean cyst nematode, Heterodera glycines Ichinohe, in one of the most serious threats for this crop, considered as its most destructive parasite. The first report of this disease in Brazil was recorded during the 1991/1992 harvest. Control of nematodes is more challenging if compared with other plant diseases control. Thus, there is a growing demand to search for alternative control practices that will not harm the environment nor the human being. Therefore, the highly specific bacteria Pasteuria spp. Metchnikoff, represents an auspicious biological control agent against nematodes. The biological control of the soybean cyst nematode with the bacterium Pasteuria nishizawae Sayre has proven an excellent choice and has been studied by different scientists. The objective of this work was to determine the natural occurrence of Pasteuria nishizawae in Brazilian soils. The experiment was performed under greenhouse conditions at the Research unit from Syngenta ${ }^{\circledR}$ in Uberlandia-MG, Brazil, with soil samples originated from soybean planted areas from the Brazilian states of Bahia, Goiás, Mato Grosso and Paraná. Fractions of $150 \mathrm{~cm}^{3}$ of soil were withdrawn to be processed by the centrifugal flotation technique in sucrose solution. Aliquots of $1 \mathrm{~mL}$ from the obtained suspension were observed in Peters' chamber with the aid of an inverted light microscope, in order to verify the absence or presence of bacterial endospores attached to the cuticle of the nematodes extracted from the soil samples. The frequency of Pasteuria nishizawae incidence was of $100 \%$ within the samples analyzed.
\end{abstract}

KEYWORDS: Bacteria, Biological control, Cyst nematode, Glycine max.

\section{INTRODUCTION}

Soybean is a crop of economic importance, being the most planted oilseed in the world. Brazil is the second largest producer and exporter of soybean in the world, with a planted area of approximately 26,4 to 27,3 million hectares and a production of about 80,08 to 82,99 million tons in $2012 / 2013$ (CONAB, 2013).

The soybean cysts nematode (SCN), Heterodera glycines, is one of the most severe plant disease problems of this crop, considered as the most destructive parasite of soybean plants (NOEL, 1992).

In order to control these nematodes the primary common methods used are chemical control (nematicides), the use of resistant varieties and crop rotation. Chemical control by means of nematicide application has proven expensive as well as detrimental to the environment, to the human being, to the wild fauna and to the beneficial organism within the soil. The use of resistant varieties is a natural approach, highly recommended to control plant pests and diseases. However, in the case of this specific nematode, the availability of resistant varieties for the farmer is scarce, due to the great number of races or HG types of SCN occurring in Brazil (FERRAZ; FREITAS, 2004).
In tropical and subtropical countries nematodes find ideal humidity and temperature conditions for reproduction and feeding. Thus, worsening the efficiency of control of these pathogens, that are very difficult to eradicate once they are established within an area (TORRES et al., 2008).

Biological control is an alternative method to control plant parasites, as nematodes. Biological control of nematodes can be achieved by the use of appropriate fungi or bacteria. Predators and egg parasites are certainly the most studied organism and the best fitted as nematode's biological control agents (JATALA, 1986; NORDBRING-HERTZ et al., 2002).

The first observation of Pasteuria in a plant parasite nematode, Pratylenchus pratensis de Man, was made by Thorne (1940) whom classified the organism as a Protozoa and named it as Dubosquia penetrans. However, studies performed by Mankau (1975), re-classified the organism as a prokaryote of the Genus Bacillus Cohn. The re-discovery of Pasteuria ramose by Sayre et al. (1977) and its morphological similarities with Bacillus penetrans Mankau suggested that these two bacteria had a common generic relation. In 1985, Sayre and Starr named the organism that parasite Meloidogyne incognita as Pasteuria penetrans (Thorne) Sayre \& Starr, as well as Pasteuria nishizawae is specific to 
the soybean cysts nematode (Heterodera glycines), Pasteuria thornei Sayre \& Starr is specific to the nematode of the root lesions according to Stirling \& Wachtel (1980), while Pasteuria usgae is specific to the nematode Belonolaimus longicaudatus Rau according to Rau Giblin- Davis et al. (2003).

Pasteuria is a gram-positive bacterium that forms an endospore. These bacteria were found as parasites of many economically important nematodes (SAYRE; STARR 1988). The Genus Pasteuria spp. was structured from 323 nematode species belonging to 116 Genera, including plant parasitic nematodes, entomopathogenic nematodes, predator nematodes and free living nematodes (CHEN; DICKSON 1998).

The analysis of the 16S rRNA gene sequences is a sensible and well-established tool for the detection and phylogenetic analysis of bacteria (STAHL, 1997). The use of sequences of the gene 16S rRNA may lead to identification of species of Pasteuria and to evaluation of the diversity of these microorganisms within a population of nematodes' samples, thus being a tool of a great utility for the comprehension of the parasite-nematode interactions and the ecology of Pasteuria (EBERT et al., 1996; ANDERSON et al., 1999; ATIBALENTJA et al., 2000; BEKAL et al., 2001).

All Pasteuria species known are obligate parasites. Until recently the Genus had four species Pasteuria nishizawae, $P$. penetrans, $P$. ramosa and $P$. thornei (OOSTENDORP et al., 1990; Chen; Dickson, 1998).

For many years attempts to obtain an axenic culture of Pasteuria spp. resulted in failure (WILLIAMS et al., 1989; BISHOP; ELLAR, 1991). However, an advance towards the success to obtain an in vitro culture of $P$. penetrans was announced by Hewlett et al. (2002).

A life cycle study of the bacterium that parasites the nematode Heterodera glycines was performed by means of germination of the endospore that infects J2's for production of a next generation endospores in adult females and cysts. Descriptions were based in microscopic examination of successive juvenile stages of $H$. glycines excised from soybean roots, unlike $P$. nishizawae, that were based exclusively on the examination of diseased cysts (SAYRE et al., 1991).

According to Atibalentja et al. (2004), bacterium development, germination of the endospore and penetration of the germ tube inside the nematode begin soon after penetration of the J2's in the radicular system. Otherwise, the endospore does not germinate and consequently no infection by Pasteuria will arise. For this reason, observations based only on diseased cysts will result in an incomplete analysis of Pasteuria's life cycle, which would explain why germination of $P$. nishizawae is not observed (SAYRE et al., 1991).

After the endospore's germination, primary cauliflower-like colonies are formed within the J3. Development of the bacterium was observed only in female adults but not in males. Later, the bacterial sporulation can be observed with the development of a structure similar to a chunk of grapes, which can be observed also in immature females of fourth stage and cysts. Finally, the presence of mature sporangia and endospores can be observed, varying in number (30.000 to 820.000 with mean value and standard deviation of 314.00 and 234.000, respectively) as a function of the size of the cyst or female nematode (ATIBALENTJA et. al., 2004).

Until now, $P$. penetrans is the most studied species due to its potential as a biological control agent. However, technical hitches for mass production in vitro had made its commercial production problematic. In order to introduce bacteria in the soil environment for field experiments, dry roots' powder infected by the bacteria was used, as proposed by Stirling and Wachtel (1980).

Thus, the objective of the present work was to verify the natural occurrence of Pasteuria nishizawae Sayre in soils under soybean cultivation.

\section{MATERIAL AND METHODS}

Soil samples with cysts coming from different established soybean growing areas from Brazil (Table 1), were processed by the centrifugal flotation in sucrose solution technique (Jenkins, 1964).

Part of those ten processed soil samples were added, individually, to ceramic pots and preserved under greenhouse at Syngenta's experimental station in Uberlândia, MG - Brazil. These pots were planted with the susceptible soybean cultivar 'Lee 74E', in order to promote multiplication of Heterodera glycines, as shown in Figure 1. 
Table 1. Place of origin of the samples analyzed in the essay for natural occurrence of Pasteuria nishizawae in Brazilian soils.

\begin{tabular}{ccc}
\hline Identification & County & State \\
\hline H.g 1 & Jataí & GO \\
H.g 2 & Sorriso & MT \\
H.g 3 & Campo Alegre & GO \\
H.g 4 & Lucas do Rio Verde & MT \\
H.g 5 & Luís Eduardo Magalhães & BA \\
H.g 6 & Campo Alegre & GO \\
H.g 7 & Nova Mutum & MT \\
H.g 8 & Campo Alegre & GO \\
H.g 9 & Luís Eduardo Magalhães & BA \\
H.g 10 & Londrina & PR \\
\hline
\end{tabular}

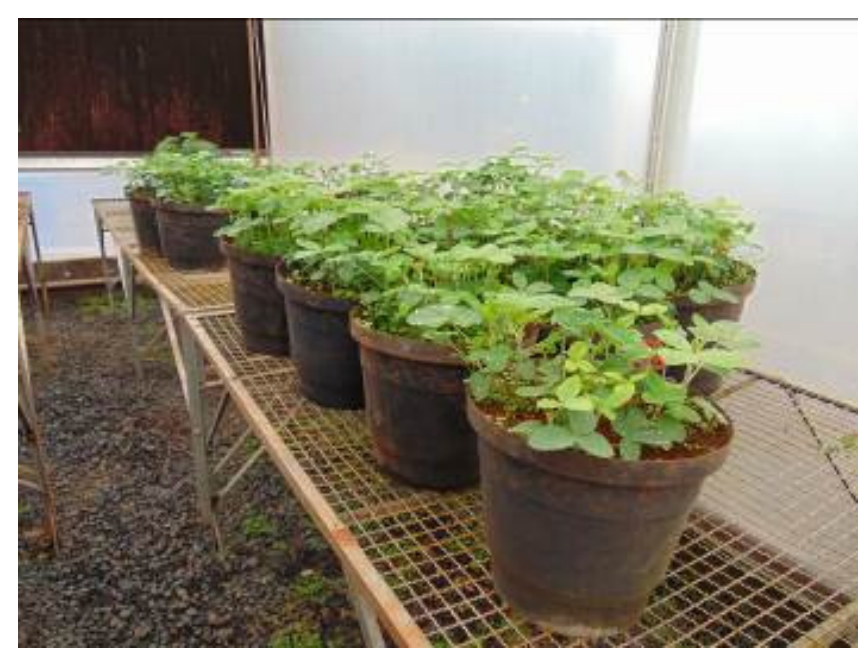

Figure 1. Populations of Heterodera glycines originated from field soil samples, being multiplied and preserved under greenhouse conditions.

A soil aliquot of $150 \mathrm{~cm}^{3}$ was obtained 28 days after sowing and then processed by the centrifugal flotation in sucrose solution technique, according Jenkins (1964).

From the obtained suspension solution an aliquot of $1 \mathrm{~mL}$ was observed in Peters chamber under an inverted light microscope, verifying the presence or absence of endospores of the bacterium attached to the nematode's cuticle (Figure 2). Subsequently, the percentage of nematodes showing bacteria attached to its body in relation to the total number of nematodes observed in the suspension was calculated.

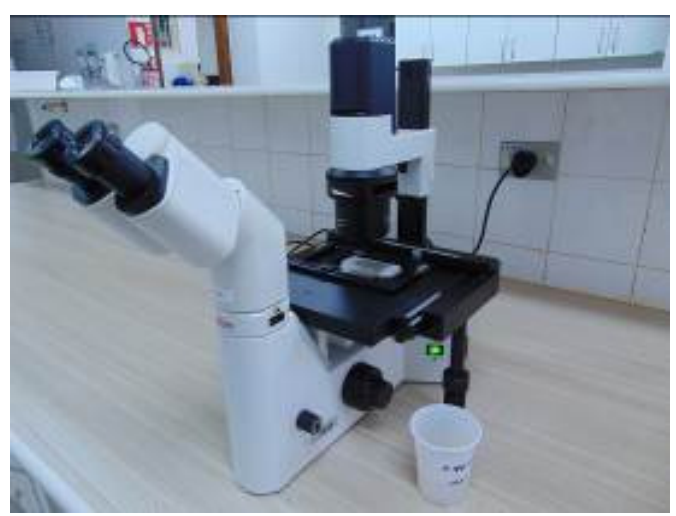

Figure 2. Counting of nematodes in suspension solution with the aid of a Peters' chamber under an inverted light microscope to observe bacterial endospores. 


\section{RESULTS AND DISCUSSION}

Within all ten samples the frequency of occurrence of the bacterium Pasteuria nishizawae was of $100 \%$, that is to say, there were observed bacterial endospores attached to the cuticle of all the nematodes Heterodera glycines extracted from the soil 28 days after soybean sowing (Table 2), as showed in Figure 3.

Table 2. Natural occurrence and frequency of Pasteuria nishizawae in samples originated from different districts in Brazil.

\begin{tabular}{ccc}
\hline Sample identification & $\begin{array}{c}\text { Total number of } \\
\text { H. glycines 2nd stage } \\
\text { juveniles recovered }\end{array}$ & $\begin{array}{c}\text { Frequency of attached endospores } \\
\text { of } \\
\text { P. nishizawae (\%) }\end{array}$ \\
\hline H.g 1 & 720 & 100 \\
H.g 2 & 294 & 100 \\
H.g 3 & 294 & 100 \\
H.g 4 & 396 & 100 \\
H.g 5 & 156 & 100 \\
H.g 6 & 76 & 100 \\
H.g 7 & 442 & 100 \\
H.g 8 & 105 & 100 \\
H.g 9 & 90 & 100 \\
H.g 10 & 116 & 100 \\
\hline
\end{tabular}
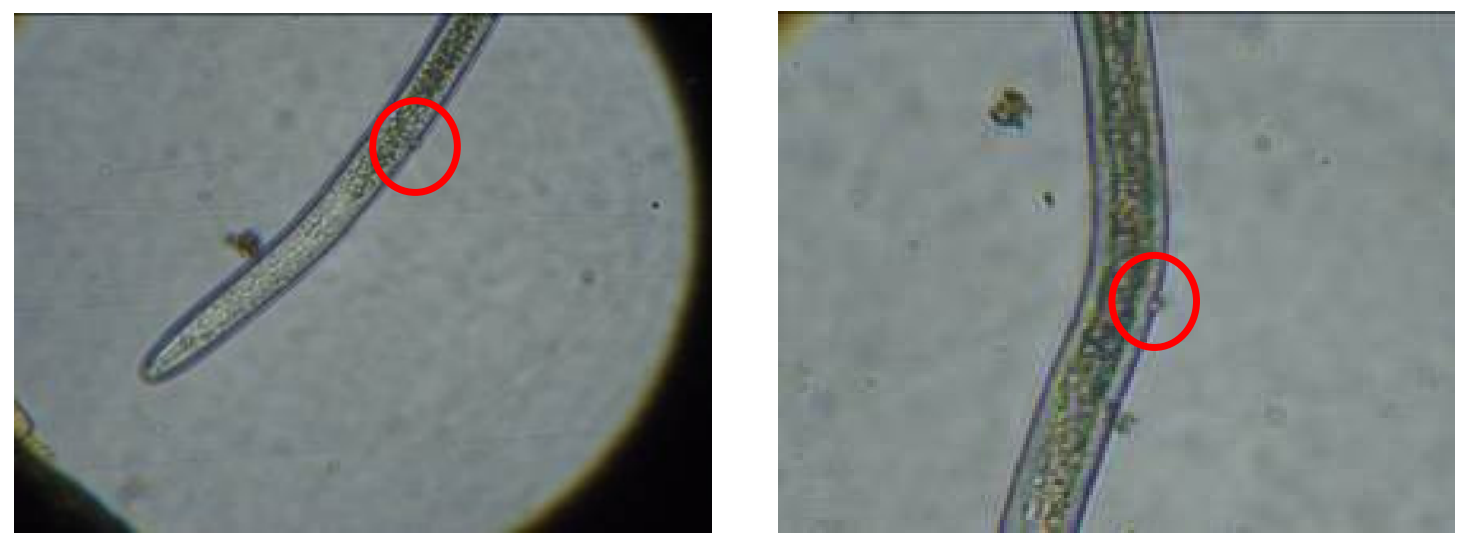

Figure 3. Observation of juvenile nematodes with Pasteuria nishizawae endospores attached to their cuticle.

In Brazil, studies regarding Pasteuria spp. are still developing, especially when concerning to its employment to control species of Pratylenchus and Heterodera. The vast majority research about the subject is developed in the country focusing the root-knot nematode (Meloidogyne spp.).

According to Tzortzakakis and Gowen (1994), a great number of endospores attached to the J2 nematodes, does not ensure reduction in the number of eggs produced, if a high variance of attachment and infectivity of endospores occurs. These remain viable in the soil by many years, are resistant to desiccation (STIRLING, 1984) and relatively resistant to high temperatures.

Lordello (1966) reported for the first time in Brazil, the occurrence of Pasteuria spp. in females of Meloidogyne javanica, infecting plants of tomato coming from Vargina in Minas Gerais.

Santos (1981), observed the bacterium in juveniles of the second stage of $M$. javanica extracted from soil collected from the rhizosphere of bean plants intensively infected by the nematode in Petrolina, Pernambuco. Subsequently, several works were performed on the parasitism of Pasteuria spp. in nematodes, verifying in the average, activity of the bacterium over Meloidogyne species (PIMENTA; CARNEIRO, 2005).

According to Souza and Campos (1996), Pasteuria spp. was observed in $29,69 \%$ of the samples collected in 128 locations and 28 vegetal species in Minas Gerais, similar results were also verified in other countries: South Africa (Spaull, 1984), Australia (STIRLING; WHITE, 1982; BIRD; 
BRISBANE, 1988), USA (WALTER; KAPLAN, 1990; HEWLETT et al., 1994) and Spain (VERDEJO; LUCAS, 1992). These authors observed infection percentages of $14,61 \%, 8,66 \%$, $7,30 \%$ and $4,21 \%$ respectively, on populations of Helicotylenchus dihystera (Cobb) Sher, Meloidogyne javanica Goeldi, Pratylenchus brachyurus Godfrey and Tylenchus sp. Bastian extracted from the soil.

There is no record of the occurrence of Pasteuria spp. in regions with annual mean temperature under $10^{\circ} \mathrm{C}$, with the higher occurrence being observed under annual mean temperatures above $21^{\circ} \mathrm{C}$ (CHEN; DICKSON, 1998).

\section{CONCLUSIONS}

Pasteuria nishizawae has natural occurrence in Brazilian soils under soybean cultivation, specifically in the States of Bahia, Goiás, Mato Grosso and Paraná.

The frequency of Pasteuria nishizawae occurence within the analyzed soils was of $100 \%$.

\section{ACKNOWLEDGMENTS}

The author would like to thank Syngenta's experimental station staff at Uberlândia - MG, where this research was performed.

RESUMO: A soja (Glycine max (L.) Merrill) é uma cultura de grande importância econômica. O Brasil é o segundo maior produtor e exportador mundial. Um dos mais sérios problemas fitossanitários desta cultura é o nematoide do cisto, Heterodera glycines Ichinohe, considerado o parasito mais destrutivo. A primeira ocorrência desta doença no Brasil foi relatada na safra 1991/1992. O controle de nematoides é mais difícil quando comparado com outras doenças. Torna-se cada vez mais importante a busca de controle alternativo, que não ofereça risco ao meio ambiente e nem ao aplicador. Sendo assim, a bactéria Pasteuria spp. Metchnikoff com alta especificidade, representa um promissor agente de controle biológico dos nematoides. O controle biológico do nematoide do cisto da soja pela bactéria Pasteuria nishizawae Sayre vem sendo estudado por diversos pesquisadores. O objetivo deste trabalho foi determinar a ocorrência natural de Pasteuria nishizawae em solos brasileiros. O ensaio foi conduzido em casa-de-vegetação na Unidade de Pesquisa da Syngenta em Uberlândia - MG, com amostras de solo provenientes de áreas de cultivo de soja dos estados brasileiros Bahia, Goiás, Mato Grosso e Paraná. Foram retiradas uma alíquota de $150 \mathrm{~cm}^{3}$ de solo e então a mesma foi processada pela técnica da flotação centrífuga em solução de sacarose. Da suspensão obtida foi observada uma alíquota de $1 \mathrm{~mL}$ em câmara de Peters, com o auxílio do microscópio invertido, verificando a presença ou ausência de endósporos da bactéria aderidos na cutícula dos nematoides extraídos. A frequência de ocorrência da Pasteuria nishizawae foi de $100 \%$ nas amostras analisadas.

PALAVRAS-CHAVE: Bactéria. Controle biológico, Nematoide de cisto, Glycine max.

\section{REFERENCES}

ANDERSON, J. M.; PRESTON, J. F.; DICKSON, D. W.; HEWLETT, T. E.; WILLIAMS, N. H.;

MARUNIAK, J. E. Phylogenetic analysis of Pasteuria penetrans by $16 \mathrm{~S}$ rRNA gene cloning and sequencing. Journal of Nematology. College Park, v. 31, p. 319-325, 1999.

ATIBALENTJA, N. G.; NOEL, G. R.; DOMIER, L. L. Phylogenetic position of the North American isolate of Pasteuria that parasitizes the soybean cyst nematode, Heterodera glycines, as inferred from the 16S rDNA sequence analysis. Int J Syst Evol Microbiol. Reading, v. 50, p. 605-613, 2000.

ATIBALENTJA, N.; JAKSTYS, B.P.; NOEL, G. R. Life Cycle, Ultrastructure, and Host Specificity of the North American Isolate of Pasteuria that Parasitizes the Soybean Cyst Nematode, Heterodera glycines.

Journal of Nematology. College Park, v. 36, n. 2, p. 171-180. 2004.

BEKAL, S.; BOMEMAN, J.; GIBLIN-DAVIS, R. M.; BECKER, J. O. Phenotypic and molecular analysis of a Pasteuria strain parasitic to the sting nematode. Journal of Nematology. College Park, v. 33, p. 110-115, 2001.

BIRD, A. F.; BRISNANE, P. G. The influence of Pasteuria penetrans in field soils on the reproduction of rootknot nematodes. Rev. Nematol. [S.1], v. 11, n. 1, p. 75-81, 1988. 
BISHOP, A. H.; ELLAR, D. J. Attempts to culture Pasteuria penetrans in vitro. Biocontrol Science and Technology. Hauppauge, v. 1, p. 101-114, 1991. http://dx.doi.org/10.1080/09583159109355190

CHEN, Z. X.; DICKSON, D. W. Review of Pasteuria penetrans: Biology, ecology, and biological control potential. Journal of Nematology. College Park, v. 30, p. 313-340, 1998.

CONAB - Companhia Nacional de Abastecimento. 2013. Acompanhamento da Safra Brasileira. <http://agricultura.ruralbr.com.br/noticia/2013/02/conab.> acesso em 23 de novembro de 2013.

EBERT, D.; RAINEY, P.; EMBLEY, T. M.; SCHOLZ, D. Development, life cycle, ultrastructure and phylogenetic position of Pasteuria ramosa Metchnikoff 1888: rediscovery of an obligate endoparasite of Daphnia magna Straus. Philos Trans R Soc Lond B. London, v. 351, p. 1689-1701, 1996.

FREITAS, L. G.; OLIVEIRA, R. D. L.; FERRAZ, S. Introdução à nematologia. Viçosa: Editora UFV, 2004. 84p. (Caderno didático, 58).

GIBLIN-DAVIS, R. M.; WILLIAMS, D. S.; BEKAL, S.; DICKSON, D.W.; BRITO, J. A.; BECKER, J. O.; PRESTON, J. F. 'Candidatus Pasteuria usgae' sp. nov., an obligate endoparasite of the phytoparasitic nematode Belonolaimus longicaudatus. Int J Syst Evol Microbiol. Reading, v. 53, p. 197-200, 2003.

HEWLETT, T. E.; COX, R.; DICKSON, D. W.; DUNN, R. A. Occurrence of Pasteuria sp. In Florida. Journal of Nematology. College Park, v. 26, n. 4, p. 616-619, 1994.

HEWLETT, T. E.; GERBER, J. F.; SMITH, K. S.; WHITE, J. H. In vitro culture of Pasteuria penetrans. Journal of Nematology. College Park, v. 4, p: 152-153 (Abstr.), 2002.

JATALA, P. Biological control of plant-parasitic nematodes. Annual Review of Phytopathology. Palo Alto, v. 24, p. 453- 489, 1986. http://dx.doi.org/10.1146/annurev.py.24.090186.002321

JENKINS, W. R. A rapid centrifugal - flotation technique for separating nematodes from soil. Plant Diasease Report. [S.1], v. 48, p. 692, 1964.

LORDELlO, L. G. E. Nota sobre um parasito de nematoide. Revista de Agricultura. [S.1], v. 41, n. 2, p. 6769, 1966.

MANKAU, R. Bacillus penetrans n. comb. causing a virulent disease of plant-parasitic nematodes. J Invertebr Pathol. New York, v. 26, p. 333-339, 1975.

NOEL, G. R. History, distribution and economics. In: RIGGS, R. D.; WRATHER, J. A., eds. Biology and management of the soybean cyst nematode. St. Paul: The American Phytopathological Society. St. Paul, p. 13, 1992. http://dx.doi.org/10.1017/S0022050700011840

http://dx.doi.org/10.1017/S0022050700011487

NORDBRING-HERTZ, B.; JANSSON, H. B.; TUNLID, A. Nematophagous fungi. In: Encyclopedia of Life Sciences. Chichester, Macmillan Publishers, Basingstoke, 10 p, 2002.

OOSTENDORP, M.; DICKSON, D. W.; MITCHELL, D. J. Host range and ecology of isolates of Pasteuria spp. from the southern United States. Journal of Nematology. College Park, v. 23, p. 525-531, 1990.

PIMENTA, C. A. M.; CARNEIRO, R. M. D. G. Utilização Pasteuria penetrans em controle biológico de Meloidogyne javanica em duas culturas sucessivas de alface e tomate. Embrapa Recursos Genéticos e Biotecnologia. Brasília, 2005. 36 p. (Boletim de Pesquisa e Desenvolvimento, 116). 
SANTOS, J. M. Ocorrência de Bacillus penetrans parasitando Meloidogyne javanica (Nematoda:

Meloidogynidae) no Brasil. Fitopatologia Brasileira. Brasilia, v. 6, n. 4, p. 519-522, 1981.

SAYRE, R. M.; WERGIN, W. P.; DAVIS, R. E. Occurrence in Monia rectirostris (Cladocera: Daphnidae) of a parasite morphologically similar to Pasteuria ramosa (Metchnikoff, 1888). Canadian Journal of Microbiology. Ottawa, v. 23, p. 1573-1579, 1977. http://dx.doi.org/10.1139/m77-232

SAYRE, R. M.; STARR, M. P. Pasteuria penetrans (ex Thorne, 1940) nom. ver. Comb. N., sp.n.a mycelial and endospore-forming bacterium parasitic in plant parasitic nematodes. Proceedings of the Helmintological Society of Washington. Lawrence, v. 52, p. 149-165, 1985.

SAYRE, R. M.; STARR, M. P. Bacterial diseases and antagonisms of nematodes. In Diseases of Nematodes. Edited by G. O. Poinar, Jr \& H.-B. Jonson. Boca Raton. FL: CRC Press, p. 59 - 101, 1988.

SAYRE, R. M.; WERGIN, W. P.; NISHIZAWA, T.; STARR, M. P. Light and electron microscopical study of a bacterial parasite from the cyst nematode, Heterodera glycines. Journal of the Helminthological Society of Washington. Lawrence, v. 58, p. 69-81, 1991.

SOUZA, J. T.; SOUZA, R. M. de; CAMPOS, V. P. Ocorrência e flutuação populacional de Pasteuria spp. em Minas Gerais. Nematologia Brasileira. Piracicaba, v. 20, n. 2, p. 41-51, 1996.

SPAULL, V, W. Observation on Bacillus penetrans infecting Meloidogyne in sugarcane fields in South Africa. Revue Nématol. Montrouge Cedex, v. 7, n. 3, p. 277-282, 1984.

STAHL, D. A. Molecular approaches for the measurement of density, diversity and phylogeny. In: Manual of Environmental Microbiology. pp. 102-114. Edited by C. J. Hurst, G. R. Knudsen, M. J. McInerney, L. D. Stetzenbach \& M. V. Walter. Washington, DC: American Society for Microbiology, 1997.

STIRLING, G. R. Biological control of Meloidogyne javanica with Bacillus penetrans. Phytopathology. St. Paul, v. 74, n. 1, p. 55-69, 1984. http://dx.doi.org/10.1094/Phyto-74-55

STIRLING, G. R.; WACHTEL, M. F. Mass production of Bacillus penetrans for the biological control of rootknot nematodes. Nematologica, Leiden, v. 26, p. 308-312. 1980. http://dx.doi.org/10.1163/187529280X00260

STIRLING, G. R.; WHITE, A. M. Distribution of a parasite of root-knot nematodes in South Australia vineyards. Plant Disease. St. Paul, v. 66, n. 1, p. 52-53, 1982. http://dx.doi.org/10.1094/PD-66-52

THORNE, G. Dubosqia penetrans n. sp. (Sporozoa: Microsporidia,Nosematidae), a parasite of the nematode Pratylenchus pratensis (de Man) Filipjev. Proceedings of the Helminthological Society of Washington. 7, p. 51-53, 1940.

TORRES, R. G.; RIBEIRO, N. R.; BOER, C. A.; Manejo de nematoides no SPD cerrados -2008. (Circular Técnica). Disponível em www.monsoy.com.br.

Acesso em: 12 de nov. 2014.

TZORTZAKAKIS, E. A.; GOWEN, S. R. Evaluation of Pasteuria penetrans alone and in combination with oxamyl, plant resistance and solarization for control of Meloidogyne spp. on vegetables grown in greenhouses in Crete. Crop Protection. Guildford, GB, v. 13, p. 455-462, 1994.

VERDEJO-LUCAS, S. Seasonal population fluctuations of Meloidogyne spp. and the Pasteuria penetrans group in kiwi orchards. Plant Disease. St. Paul, v. 26, n. 12, p. 1275-1279, 1992. http://dx.doi.org/10.1094/PD76-1275

WALTER, D. E.; KAPLAN, D. T. Antagonists of plant-parasitic nematodes in Florida citrus. Journal of Nematology. College Park, v. 22, n. 4, p. 567-573, 1990. 
WILlIAMS, A. B., STIRLING, G. R., HAYWARD, A. C.; PERRY, J. Properties and attempted culture of Pasteuria penetrans, a bacterial parasite of root-knot nematode (Meloidogyne javanica). Journal of Applied Bacteriology. Oxford, v. 67, p. 145-156. 1989. http://dx.doi.org/10.1111/j.1365-2672.1989.tb03389.x 